\title{
International Trade Openness and Monetary Policy: Evidence from Cross-Country Data
}

\author{
Fernando Leibovici
}

\begin{abstract}
This article studies the extent to which open economies conduct monetary policy differently from economies that are relatively closed to international trade. I first estimate country-specific Taylor rules for 26 economies, following the approach of Clarida, Galí, and Gertler (1998 and 2000). Then, I examine the extent to which open economies assign systematically different weights to changes in economic outcomes, such as inflation and the output gap, than their closed economy counterparts do. I find that open economies respond less strongly to changes in expected inflation than relatively closed economies do and that the response to changes in the output gap is independent of the degree of trade openness. Moreover, I find that this difference between closed and open economies may be accounted for by the higher weight open economies give to changes in the real exchange rate, whereby these economies are more likely to decrease the nominal interest rate when the real exchange rate is relatively appreciated. (JEL E5, F1, F41)
\end{abstract}

Federal Reserve Bank of St. Louis Review, Second Quarter 2019, 101(2), pp. 93-113.

https://doi.org/10.20955/r.101.93-113

\section{INTRODUCTION}

Open economies are typically exposed to different sources of shocks than economies relatively closed to international trade ${ }^{1}$ : To the extent that a country trades goods with the rest of the world, economic conditions in its trade partners and changes in international relative prices may affect domestic economic activity. Insofar as central banks design monetary policy to moderate business cycle fluctuations, the different nature of business cycles in open economies has led many to ask, to what extent should central banks in open economies conduct monetary policy differently from their closed-economy counterparts?

In a recent study, Leibovici and Santacreu (2015) find that openness should indeed be an important consideration for the design of monetary policy. In particular, we show that international trade fluctuations play a key role in accounting for the optimal monetary policy that central banks in open economies should conduct. This finding suggests that trade openness should be a key factor in optimal monetary policy design.

Fernando Leibovici is an economist at the Federal Reserve Bank of St. Louis. The author thanks Jonas Crews for excellent research assistance and Ana Maria Santacreu for helpful discussions.

( ) 2019, Federal Reserve Bank of St. Louis. The views expressed in this article are those of the author(s) and do not necessarily reflect the views of the Federal Reserve System, the Board of Governors, or the regional Federal Reserve Banks. Articles may be reprinted, reproduced, published, distributed, displayed, and transmitted in their entirety if copyright notice, author name(s), and full citation are included. Abstracts, synopses, and other derivative works may be made only with prior written permission of the Federal Reserve Bank of St. Louis. 
More generally, while theoretical studies have also largely concluded that open economies should indeed conduct monetary policy differently, studies differ in their policy recommendations. On the one hand, Clarida, Galí, and Gertler (2002) and Corsetti, Dedola, and Leduc (2010) show that in a specific class of economic models the design of monetary policy in open economies is "isomorphic" to the conduct of monetary policy in a closed economy: Central banks should only respond to changes in inflation and the output gap, but they may respond differently to these depending on the degree of trade openness. On the other hand, morerecent studies have shown that this need not necessarily be the case in more realistic environments (Faia and Monacelli, 2008, De Paoli, 2009, and Lombardo and Ravenna, 2014) in which central banks in open economies may also want to respond to changes in other variables such as the real exchange rate.

Yet, while much work has been devoted to understanding the normative question about whether and how central banks in open economies should design monetary policy differently from their closed-economy counterparts, much less is known about the positive question on whether they do indeed conduct policy differently. Therefore, in this article I ask, to what extent do central banks of open economies conduct monetary policy differently from those of closed economies?

The answer to this question has important implications. To the extent that the relationship between trade openness and monetary policy observed in the data differs from the relationship implied by the optimal policy analysis of structural economic models, this may suggest that some countries are indeed conducting monetary policy suboptimally. Alternatively, to the extent that central banks of open economies conduct monetary policy differently from that implied by standard models, this may reflect economic channels or concerns of policymakers that may not be explicitly considered in the economic models, but which may yet be important for understanding the link between trade openness and monetary policy.

The goal of this article is, thus, to investigate the empirical relationship between trade openness and the design of monetary policy using cross-country time-series data for the period 1980 to 2006. In the first step of the analysis, I compute empirical measures that allow me to characterize and compare the nature of monetary policy across different countries over this period. Then, I use these empirical measures to examine whether open economies conduct monetary policy differently from closed economies.

My starting point to characterizing the nature of monetary policy across countries is the standard Taylor rule (1993), which specifies a link among nominal interest rates, inflation, and the output gap. While an increasing number of countries use the nominal interest rate as their preferred instrument for the conduct of monetary policy combined with some sort of inflation and/or output-related targets, the approach I take here is more broad. In particular, in this article I do not interpret the Taylor rule coefficients as structural parameters that govern the response of interest rates to changes in inflation and output but, instead, use the Taylor rule as a device to summarize the statistical properties of how interest rates, inflation, and output behave in the time series across countries regardless of the particular underlying monetary policy instruments, outcome-targeting regimes, or exchange rate regimes in place in each country. 
The goal of this approach is to characterize monetary policy across countries through a common lens in order to facilitate cross-country comparability. This advantage comes at the cost of forcing the analysis to abstract from differences in monetary policy across countries not captured by differences in the empirical Taylor rule coefficients.

Thus, I first estimate country-specific Taylor rules for 26 countries with differing degrees of openness to international trade (as measured by the ratio of aggregate exports to gross domestic product [GDP]) using time-series data on interest rates, inflation, and output. I follow the generalized method of moments (GMM) approach of Clarida, Galí, and Gertler (1998 and 2000), which allows me to obtain estimates of the explicit or implicit response of interest rates to changes in inflation and the output gap. Then, I examine whether the statistical relationship among interest rates, inflation, and output differs systematically based on the degree of trade openness.

I begin the analysis by considering a baseline specification of the Taylor rule, which specifies the relationship among nominal interest rates, expected inflation, and the current output gap. In addition, I include lagged nominal interest rates, following a large literature that has observed that central banks adjust interest rates gradually over time. I find considerable dispersion across countries in the empirical relationship between nominal interest rates and expected inflation, as well as between nominal interest rates and the output gap. Moreover, I find that these relationships differ systematically across countries based on their degree of international trade openness: Nominal interest rates in open economies respond systematically less to changes in expected inflation than they do in closed economies. I find no systematic relationship between the response of a country's nominal interest rate to changes in its output gap and the degree of the country's openness.

While the lower response of nominal interest rates in open economies to changes in inflation may reflect that such countries are less concerned about inflation, it may also reflect that these countries actually respond to changes in variables other than inflation. To investigate this possibility, I reconduct the analysis, extending the Taylor rule to include a trade-related variable that may affect how open economies conduct monetary policy, as suggested by previous studies (Faia and Monacelli, 2008, and De Paoli, 2009, among others) - the real exchange rate. I find that, indeed, open economies are systematically more likely to adjust their nominal interest rate in response to changes in the real exchange rate.

These findings suggest that open economies do conduct monetary policy differently from their closed-economy counterparts. First, I find that open economies respond relatively less to changes in inflation. Second, I find that open economies respond relatively more to changes in the real exchange rate. And, finally, I find that the degree of interest rate smoothing and the response of nominal interest rates to changes in the output gap do not vary systematically with the degree of international trade openness.

This article contributes to a growing empirical literature that studies the relationship between trade openness and monetary policy, such as Lubik and Schorfheide (2007), Berument, Konac, and Senay (2007), and Basilio (2013). This article is also related to empirical papers aimed at estimating Taylor rules across countries. I follow very closely the estimation approach of Clarida, Galí, and Gertler (1998 and 2000), who apply it to the United States, Japan, Germany, 
France, Italy, and the United Kingdom. Also related are Torres (2003), Hayo and Hofmann (2006), Yazgan and Yilmazkuday (2007), and Kahn (2012).

More broadly, this article is also related to a large theoretical and quantitative literature that investigates the extent to which open economies should conduct monetary policy differently. Corsetti, Dedola, and Leduc (2010) provide a broad discussion of many of the studies in this literature. More recently, Faia and Monacelli (2008), De Paoli (2009), Lombardo and Ravenna (2014), and Leibovici and Santacreu (2015) investigate this question in richer and more realistic economic environments.

The rest of this article is structured as follows. Section 2 presents the economic framework, and Section 3 presents my approach to estimating it. Section 4 presents the data that I use to estimate the economic framework and describes the details of the implementation. Sections 5 and 6 present the results, and Section 7 concludes.

\section{THE TAYLOR RULE}

The starting point of the analysis is the Taylor rule, an equation that specifies the nominal short-term interest rate target as a function of three variables: (i) the long-run equilibrium nominal rate, (ii) deviations of inflation from an inflation target, and (iii) deviations of output from a target level of output. In addition, I consider an extension of the standard Taylor rule to allow for the possibility that nominal interest rates also respond to other variables. Mathematically, we have

$$
R_{t}^{*}=\bar{R}+\beta\left[\mathbb{E}\left(\pi_{t+1} \mid \Omega_{t}\right)-\pi^{*}\right]+\gamma\left[\mathbb{E}\left(y_{t} \mid \Omega_{t}\right)-y_{t}^{*}\right]+\boldsymbol{\xi}_{\mathbf{t}},
$$

where $\bar{R}$ is the long-run equilibrium nominal rate; $\pi_{t+1}$ is the rate of inflation between periods $t$ and $t+1 ; y_{t}$ is real output; $\pi^{*}$ is the target level of inflation; $y_{t}^{*}$ is the target level output; and $\mathbf{z}_{\mathbf{t}}$ is a vector of additional variables that the monetary authority may respond to. Moreover, $\mathbb{E}$ is the expectation operator and $\Omega_{t}$ is the information set available to the central bank at the time it sets interest rates. A variety of specifications of the Taylor rule have been considered in the literature; here, I focus on the specification studied by Clarida, Galí, and Gertler (1998 and 2000).

I assume that, every period, the effective short-term nominal interest rate $R_{t}$ adjusts partially to the nominal interest rate target $R_{t}^{*}$ according to the following $\mathrm{AR}(2)$ process:

$$
R_{t}=\left(1-\rho_{1}-\rho_{2}\right) R_{t}^{*}+\rho_{1} R_{t-1}+\rho_{2} R_{t-2}+v_{t}
$$

where $\rho_{1} \in(0,1)$ and $\rho_{2} \in(0,1)$ capture the degree of interest rate smoothing, $v_{t}$ is a zeromean independent and identically distributed (i.i.d.) shock to the nominal interest rate, and $\rho_{1}+\rho_{2}<1$.

Then, given the above expressions for the target short-term nominal interest rate (equation (1)) and the nominal interest rate (equation (2)), the actual nominal short-term interest rate can be expressed as 


$$
\begin{aligned}
R_{t} & =\left(1-\rho_{1}-\rho_{2}\right)\left\{\bar{R}+\beta\left[\mathbb{E}\left(\pi_{t+n} \mid \Omega_{t}\right)-\pi^{*}\right]+\gamma\left[\mathbb{E}\left(y_{t} \mid \Omega_{t}\right)-y_{t}^{*}\right]+\boldsymbol{\xi} \mathbf{z}_{\mathbf{t}}\right\} \\
& +\rho_{1} R_{t-1}+\rho_{2} R_{t-2}+v_{t}
\end{aligned}
$$

Thus, to the extent that a country's nominal interest rate follows equation (3), its evolution is characterized by

(i) a long-run value $\bar{R}$ for the nominal interest rate,

(ii) a set of outcome variables $\mathbf{X}_{t}=\left\{\mathbb{E}\left(\pi_{t+1} \mid \Omega_{t}\right)-\pi^{*}, \mathbb{E}\left(y_{t} \mid \Omega_{t}\right)-y_{t}^{*}, R_{t-1}, R_{t-2}, \mathbf{z}_{\mathbf{t}}\right\}$ on which the nominal interest rate target depends, and

(iii) a set of coefficients $\boldsymbol{\theta}=\left\{\beta, \gamma, \rho_{1}, \rho_{2}, \boldsymbol{\xi}\right\}$ that dictate the response of the nominal interest rate target to changes in the outcome variables $\mathbf{X}_{t}$.

Throughout the rest of the article, I use this framework as a lens to characterize differences in the design of monetary policy across countries. In particular, given a set of outcome variables $\mathbf{X}_{t}=\left\{\mathbb{E}\left(\pi_{t+1} \mid \Omega_{t}\right)-\pi^{*}, \mathbb{E}\left(y_{t} \mid \Omega_{t}\right)-y_{t}^{*}, R_{t-1}, R_{t-2}, \mathbf{z}_{\mathbf{t}}\right\}$ on which the nominal interest rate is assumed to depend, I estimate the set of coefficients $\boldsymbol{\theta}=\left\{\beta, \gamma, \rho_{1}, \rho_{2}, \boldsymbol{\xi}\right\}$ that dictates its response to changes in the outcome variables. From the lens of this approach, differences in the design of monetary policy across countries boil down to differences in the set of estimated coefficients $\boldsymbol{\theta}$. Then, I examine the extent to which open economies conduct monetary policy differently from closed ones by investigating whether the set of coefficients $\boldsymbol{\theta}$ varies systematically with the degree of international trade openness across countries.

Importantly, note that while I use the framework above to characterize differences in the design of monetary policy across countries, I do not necessarily restrict attention to countries with explicit interest rate targeting rules. In particular, I do not interpret the Taylor rule coefficients $\boldsymbol{\theta}$ as structural parameters that govern the response of nominal interest rates to changes in inflation and output but, instead, use the specification above as a device to summarize the statistical properties of how interest rates, inflation, and output behave in the time series across countries regardless of the particular underlying monetary policy instruments, outcometargeting regimes, or exchange-rate regimes in place in each country.

\section{ESTIMATION APPROACH}

To estimate the Taylor rule described above (equation (3)) for a given country, I follow the approach of Clarida, Galí, and Gertler (1998 and 2000). The objective is to estimate the vector of coefficients $\boldsymbol{\theta}=\left\{\beta, \gamma, \rho_{1}, \rho_{2}, \boldsymbol{\xi}\right\}$ that dictates the response of the nominal interest rate to changes in the outcome variables $\mathbf{X}_{t}$.

The first problem I face in estimating $\boldsymbol{\theta}$ using equation (3) is that $\mathbb{E}\left(\pi_{t+1} \mid \Omega_{t}\right)$ and $\mathbb{E}\left(y_{t} \mid \Omega_{t}\right)$ are unobservable. While inflation and output are regularly measured by statistical agencies across countries, this is not typically the case for the expected value of inflation and output at the time that monetary policy decisions are made.

To address this challenge, I rewrite equation (3) in terms of observable variables, following Clarida, Galí, and Gertler (1998 and 2000): 


$$
R_{t}=\left(1-\rho_{1}-\rho_{2}\right)\left[\left(\bar{R}-\beta \pi^{*}\right)+\beta \pi_{t+1}+\gamma\left(y_{t}-y_{t}^{*}\right)+\xi_{\mathbf{z}_{\mathbf{t}}}\right]+\rho_{1} R_{t-1}+\rho_{2} R_{t-2}+\varepsilon_{t}
$$

where I refer to $y_{t}-y_{t}^{*}$ as the output gap and the error term $\varepsilon_{t}$ is now given by

$$
\begin{aligned}
\varepsilon_{t} & =v_{t}-\left(1-\rho_{1}-\rho_{2}\right) \beta\left[\pi_{t+1}-\mathbb{E}\left(\pi_{t+1} \mid \Omega_{t}\right)\right] \\
& -\left(1-\rho_{1}-\rho_{2}\right) \gamma\left\{\left[y_{t}-y_{t}^{*}\right]-\left[\mathbb{E}\left(y_{t} \mid \Omega_{t}\right)-y_{t}^{*}\right]\right\} .
\end{aligned}
$$

Having addressed the first challenge, the question now is how to estimate equation (4) given data on inflation $\pi_{t+1}$ and the output gap $y_{t}-y_{t}^{*}$. Estimating it by ordinary least squares (OLS) would result in biased estimates since we would be violating the exogeneity assumption, which in this case requires that $\mathbb{E}\left[\varepsilon_{t} \mid \pi_{t+1}, y_{t}-y_{t}^{*}, \mathbf{z}_{t}, \Omega_{t}\right]=0$. To see this, note that even though $v_{t}$ may be a mean-zero i.i.d. variable, equation (5) implies that

$$
\begin{aligned}
\mathbb{E}\left[\varepsilon_{t} \mid \pi_{t+1}, y_{t}-y_{t}^{*}, \mathbf{z}_{\mathbf{t}}, \Omega_{t}\right]= & -\left(1-\rho_{1}-\rho_{2}\right) \beta\left[\pi_{t+1}-\mathbb{E}\left(\pi_{t+1} \mid \Omega_{t}\right)\right] \\
& -\left(1-\rho_{1}-\rho_{2}\right) \gamma\left\{\left[y_{t}-y_{t}^{*}\right]-\left[\mathbb{E}\left(y_{t} \mid \Omega_{t}\right)-y_{t}^{*}\right]\right\} .
\end{aligned}
$$

That is, $\mathbb{E}\left[\varepsilon_{t} \mid \pi_{t+1}, y_{t}-y_{t}^{*}, \mathbf{z}_{\mathbf{t}}, \Omega_{t}\right]$ is a function of the forecast errors for inflation and the output gap, which generically need not be equal to zero in all states of the world.

The violation of the exogeneity assumption required by OLS to produce unbiased estimates can equivalently be expressed as

$$
\mathbb{E}\left\{\left[R_{t}-\left(1-\rho_{1}-\rho_{2}\right)\left[\left(\bar{R}-\beta \pi^{*}\right)+\beta \pi_{t+1}+\gamma\left(y_{t}-y_{t}^{*}\right)+\boldsymbol{\xi}_{\mathbf{t}}\right]-\rho_{1} R_{t-1}-\rho_{2} R_{t-2}\right] \tilde{\mathbf{X}}_{t} \mid \Omega_{t}\right\} \neq 0,
$$

where $\tilde{\mathbf{X}}_{t}=\left\{\pi_{t+1}, y_{t}-y_{t}^{*}, \mathbf{z}_{\mathbf{t}}, R_{t-1}, R_{t-2}\right\}$.

To address this second challenge, I follow Clarida, Galí, and Gertler (1998 and 2000) in pursuing an instrumental-variables approach. This approach requires one to find a vector of variables $\mathbf{u}_{t}$ that are correlated with $\tilde{\mathbf{X}}_{t}$ but that are uncorrelated with $\varepsilon_{t}$ or, equivalently, uncorrelated with $v_{t}, \pi_{t}-\mathbb{E}\left(\pi_{t} \mid \Omega_{t}\right)$, and $\left[y_{t}-y_{t}^{*}\right]-\left[\mathbb{E}\left(y_{t} \mid \Omega_{t}\right)-y_{t}^{*}\right]$. In other words, the objective of this approach is to find variables $\mathbf{u}_{t}$ such that the following two properties are satisfied:

(i) non-zero correlation between instruments and outcome variables: $\mathbb{E}\left\{\tilde{\mathbf{X}}_{t} \mathbf{u}_{t} \mid \Omega_{t}\right\} \neq 0$, and

(ii) zero correlation between instruments and the error term $\varepsilon_{t}$ :

$$
\mathbb{E}\left\{\left[R_{t}-\left(1-\rho_{1}-\rho_{2}\right)\left[\left(\bar{R}-\beta \pi^{*}\right)+\beta \pi_{t+1}+\gamma\left(y_{t}-y_{t}^{*}\right)+\boldsymbol{\xi}_{\mathbf{t}}\right]-\rho_{1} R_{t-1}-\rho_{2} R_{t-2}\right] \mathbf{u}_{t} \mid \Omega_{t}\right\}=0
$$

Following Clarida, Galí, and Gertler (1998), possible elements of $\mathbf{u}_{t}$ include any lagged variable that may help to forecast inflation or the output gap. Why? By definition, the forecast error consists of the difference between the realization of a variable and its expected value conditional on the information set at the time that the nominal interest rate is determined. Then, to the extent that one identifies a lagged variable that may help to forecast either $\pi_{t+1}$ or $y_{t}-y_{t}^{*}$, such a variable should not be associated with the forecast error. Other candidate instruments $\mathbf{u}_{t}$ 
include any contemporaneous variables that are uncorrelated with the current interest rate shock $v_{t}$.

Given a set of instruments $\mathbf{u}_{t}$ that satisfy conditions (1) and (2) above, I estimate equation (4) following a GMM approach. Let $j=1, \ldots$, J index the different instruments in vector $\mathbf{u}_{t}$.

First, I define the population moment corresponding to instrument $j$ as $M_{j}=\mathbb{E}\left\{\left[R_{t}-\left(1-\rho_{1}-\rho_{2}\right)\left[\left(\bar{R}-\beta \pi^{*}\right)+\beta \pi_{t+1}+\gamma\left(y_{t}-y_{t}^{*}\right)+\boldsymbol{\xi}_{\mathbf{t}}\right]-\rho_{1} R_{t-1}-\rho_{2} R_{t-2}\right] u_{t, j} \mid \Omega_{t}\right\}=0$.

Second, I construct its empirical counterpart:

$$
\tilde{M}_{j}=\frac{1}{T} \sum_{t=1}^{T}\left\{R_{t}-\left(1-\rho_{1}-\rho_{2}\right)\left[\left(\bar{R}-\beta \pi^{*}\right)+\beta \pi_{t+1}+\gamma\left(y_{t}-y_{t}^{*}\right)+\xi_{\mathbf{z}_{\mathbf{t}}}\right]-\rho_{1} R_{t-1}-\rho_{2} R_{t-2}\right\} u_{t, j} .
$$

Third, I construct the moment condition $m_{j}$ corresponding to instrument $j$ :

$$
\begin{aligned}
m_{j} & =\tilde{M}_{j}-M_{j} \\
& =\tilde{M}_{j}-0 \\
& =\tilde{M}_{j} .
\end{aligned}
$$

Fourth, I stack all moment conditions $m_{j}$ for $j=1, \ldots, J$ into a vector $\mathbf{m}$.

Finally, given a symmetric positive-definite weighting $J \times J$ matrix $\mathbf{W}, \underline{\underline{2}}$ the GMM estimator is given by the vector $\boldsymbol{\theta}=\left\{\beta, \gamma, \rho_{1}, \rho_{2}, \xi\right\}$ of parameters that solves the following problem:

$$
\min _{\left\{\beta, \gamma, \rho_{1}, \rho_{2}, \xi\right\}} \mathbf{m}^{\mathrm{T}} \mathbf{W} \mathbf{m},
$$

where a variable with superscript $\mathrm{T}$ denotes the transpose of the variable.

\section{DATA}

To implement the estimation procedure described in the previous section, I use quarterly cross-country time-series data collected by the International Monetary Fund (IMF) and the Organisation for Economic Co-operation and Development (OECD) and accessed through Haver Analytics. $\underline{3}$

I select the variables and sources used as well as the details of the specification that I estimate under two guiding principles. First, my goal is to obtain country-specific estimates of the Taylor rule coefficients $\boldsymbol{\theta}$ that can be compared across countries. Therefore, I restrict attention to variables and data sources that maximize the number of countries available while ensuring that variables are measured under a methodology that is as similar as possible across countries. ${ }^{4}$ My second goal is, to the extent possible, to follow the estimation approach of Clarida, Galí, and Gertler (1998 and 2000), with the intention of maximizing the comparability of my findings with previous estimates from the literature.

In this section, I present the data used to estimate equation (3) under the constraint $\boldsymbol{\xi}=\mathbf{z}_{\mathbf{t}}=0$, which is the standard Taylor rule formulation. I present the corresponding results in Section 5 and consider extensions of this specification in Section 6. 


\subsection{Taylor Rule Variables}

I measure the nominal interest rate $R_{t}$ using data on central bank policy rates collected by the IMF (Haver code: C\#\#\#IC@IFS). As described by the IMF (n.d.), "The central bank policy rate (CBPR) is the rate that is used by the central bank to implement or signal its monetary policy stance. It is most commonly set by the central banks' policy making committees (e.g., the Federal Open Market Committee)." $\underline{5}$

I measure the realized inflation rate $\pi_{t+1}$ as the quarterly log change in the GDP deflator between period $t+1$ and period $t$; I obtain data on the GDP deflator from the IMF and OECD (Haver codes: C\#\#\#GJ@IFS for the IMF series and C\#\#\#GPI@OECDNAQ for the OECD series).$\underline{6}$

To measure the output gap $y_{t}-y_{t}^{*}$, I compute the log difference of real GDP from its country-specific quadratic trend. ${ }^{-}$I obtain data on real GDP from the IMF and OECD (Haver codes: C\#\#\#GDPC@IFS for the IMF series and E\#\#\#GDPC@OECDNAQ for the OECD series).

\subsection{Instruments}

Following Clarida, Galí, and Gertler (1998 and 2000), the set of instruments that I use consists of two types of variables. On the one hand, I include the first four lags of each of the Taylor rule variables as part of the instrument set. In particular, I include the following variables as instruments:

$$
R_{t-1}, R_{t-2}, R_{t-3}, R_{t-4},\left(y_{t-1}-y_{t-1}^{*}\right),\left(y_{t-2}-y_{t-2}^{*}\right),\left(y_{t-3}-y_{t-3}^{*}\right),\left(y_{t-4}-y_{t-4}^{*}\right), \pi_{t-1}^{*}, \pi_{t-2}^{*}, \pi_{t-3}^{*}, \pi_{t-4}^{*} .
$$

On the other hand, I include lags of other variables that may forecast changes in the Taylor rule variables but that are unlikely to be correlated with forecast errors. Specifically, I include lags of two variables not included in the baseline specification of the Taylor rule: an index of world commodity prices $\omega_{t}$ and country-specific effective real exchange rates $Q_{t}$. To measure world commodity prices, I use the S\&P Goldman Sachs Commodity Index (S\&P GSCI Commodity Nearby Index; Haver code GSCI@USECON). To measure country-specific effective real exchange rates, I use data from the IMF and OECD (Haver codes: C\#\#\#EIRC@IFS for the IMF series and C\#\#\#FXEF@OECDMEI for the OECD series) and the Bank for International Settlements (BIS). .8 In particular, I include the following variables as instruments:

$$
\Delta \ln Q_{t-1}, \Delta \ln Q_{t-2}, \Delta \ln Q_{t-3}, \Delta \ln Q_{t-4}, \Delta \ln \omega_{t-1}, \Delta \ln \omega_{t-2}, \Delta \ln \omega_{t-3}, \Delta \ln \omega_{t-4},
$$

where $\Delta \ln x_{t-k}=\ln x_{t-k}-\ln x_{t-k-1}$ for any variable $x$ and integer $k$.

I adopt the convention throughout that real exchange rates are measured as the relative price of a domestic consumption basket relative to a foreign consumption basket (both in domestic units), so that an increase in the real exchange rate consists of a real appreciation.

\subsection{Cleaning Up the Data}

Before using these variables to estimate country-specific Taylor rules following the GMM approach described in the previous section, I apply a few filters to ensure that there is sufficient data available for each country as well as to clean the variables used. 
First, I restrict attention to the period 1980:Q1 to $2006:$ Q4. ${ }^{-}$For each of the variables that has data available from both the OECD and the IMF, I examine for each country whether there are data available from the OECD for at least 36 consecutive quarters. If so, then I use data from the OECD for that country. Otherwise, I examine whether there are data available from the IMF for at least 36 consecutive quarters. If so, then I use data from the IMF for that country; otherwise, I exclude the country from the analysis. 10

Second, I seasonally adjust the level of all of these variables except $R_{t}$, using the X13 seasonal adjustment procedure developed by the U.S. Census Bureau. I adjust this procedure to avoid controlling for U.S.-specific seasonality patterns that may not be applicable to other countries (e.g., U.S. holidays).

Finally, I restrict attention to countries with at least 36 consecutive quarters of data in which all of the Taylor rule variables and instruments are available $\left(R_{t}, y_{t}, \pi_{t}, \omega_{t}, Q_{t}\right)$. The countries and time periods used throughout the analysis are displayed in Table 1.

\subsection{Trade Openness and GDP Per Capita}

In order to examine the extent to which monetary policy in open economies is systematically different, I measure openness to international trade as the average ratio of nominal exports to nominal GDP across the sample period (Haver codes: C\#\#\#GE@IFS and C\#\#\#GDP@IFS for the IMF series and A\#\#\#@@OECDNAQ and A\#\#\#GDP@OECDNAQ for the OECD series), both in domestic units. However, all the findings are robust to alternative measures of trade openness, such as the average ratio of nominal exports plus nominal imports to nominal GDP.

In the next section, I also sometimes control for the level of economic development, as proxied by GDP per capita, which I obtain from Penn World Tables 9.0 (output-side real GDP, purchasing-power-parity adjusted, in 2011 U.S. dollars).

\subsection{Implementation}

Throughout the next sections, I execute the GMM estimation approach described above by applying the two-step GMM estimator implemented by Stata's "gmm" command with correction for heteroskedasticity and serial correlation. That is, first I obtain parameter estimates 
based on an initial weighting matrix. Then, I compute a new weighting matrix based on those estimates. Finally, I reestimate parameters based on that weighting matrix. I correct for heteroskedasticity and serial correlation using the Newey-West kernel with four lags.

\section{BASELINE TAYLOR RULE}

In this section, I begin to analyze the extent to which open economies conduct monetary policy differently from their closed-economy counterparts. To do so, I use the Taylor rule as the lens to measure differences in the conduct of monetary policy across countries. In particular, in this section I restrict attention to a Taylor rule where the nominal interest rate responds to changes in expected inflation, the output gap, and lagged values of the nominal interest rate (as in Clarida, Galí, and Gertler, 1998 and 2000).

\subsection{Taylor Rule Coefficients}

The first step of the analysis consists of following the estimation approach described above to estimate a Taylor rule for each of the countries in the sample. Table 2 presents the estimated Taylor rule coefficients corresponding to equations (3) and (4). In addition, I also report the average degree of international trade openness as measured by the aggregate exports-to-GDP ratio.

5.1.1 Validation: Estimates for the United States. To begin with, I contrast my estimated Taylor rule coefficients for the United States with estimates from previous studies in the literature. Consistent with previous studies, I find that monetary policy in the United States places a higher weight on changes in inflation than on the output gap, and nominal interest rate adjustments are smoothed over time. For instance, in the specification that uses data series closest to the ones that I use, Clarida, Galí, and Gertler (2000) estimate a weight on expected inflation equal to 1.97 (vs. 1.35), a weight on the output gap equal to 0.55 (vs. 0.62), and an impact of lagged interest rates equal to 0.76 (vs. 0.93). $\underline{11}$

Importantly, I find that most differences between my estimates and those of Clarida, Galí, and Gertler (2000) are explained by differences in the data series used. Using exactly the same data series used by Clarida, Galí, and Gertler (2000) to estimate the second row of Table II (their baseline estimates) in their paper, I estimate a weight on expected inflation equal to 2.17 (vs. 2.15), a weight on the output gap equal to 1.23 (vs. 0.93), and an impact of lagged interest rates equal to 0.80 (vs. 0.79 ). While these data series lead to estimates that are closest to those in Clarida, Galí, and Gertler (2000), some of them are not available across a large number of countries, preventing me from conducting the cross-country analysis using these particular series.

Recall that, in this article, my choice of data series is significantly driven by my twofold goal of conducting the analysis for as many countries as possible and simultaneously using data series that are as comparable across countries as possible. An implication of this approach is that the data series that I use need not always line up exactly with the variables that the central bank in each country responds to, leading to estimated Taylor rule coefficients different from those estimated under the best possible data, as illustrated above for the United States. 
Table 2

Taylor Rule Coefficients: The Baseline Taylor Rule

\begin{tabular}{|c|c|c|c|c|c|c|}
\hline \multirow[b]{2}{*}{ Country } & \multicolumn{5}{|c|}{ Taylor rule coefficients } & \multirow[b]{2}{*}{$\begin{array}{c}\text { Trade openness } \\
\text { X/GDP }\end{array}$} \\
\hline & $\begin{array}{l}\text { Expected } \\
\text { inflation }\end{array}$ & Output gap & $\begin{array}{c}\text { Lagged } \\
\text { interest rates }\end{array}$ & Constant & $\begin{array}{c}\text { Overidentification } \\
\text { test }\end{array}$ & \\
\hline Australia & $\begin{array}{l}1.486^{* * *} \\
(0.268)\end{array}$ & $\begin{array}{c}0.612 \\
(0.430)\end{array}$ & $\begin{array}{l}0.893^{* * *} \\
(0.016)\end{array}$ & $\begin{array}{c}1.673 \\
(1.204)\end{array}$ & $\begin{array}{l}J=11.77, \chi^{2}(16) \\
p \text {-value }=0.760\end{array}$ & 0.172 \\
\hline Austria & $\begin{array}{c}0.135 \\
(0.187)\end{array}$ & $\begin{array}{l}1.033^{* * *} \\
(0.251)\end{array}$ & $\begin{array}{l}0.919^{* * *} \\
(0.019)\end{array}$ & $\begin{array}{l}4.287^{* * *} \\
(0.540)\end{array}$ & $\begin{array}{l}J=10.30, \chi^{2}(16) \\
p \text {-value }=0.851\end{array}$ & 0.339 \\
\hline Bolivia & $\begin{array}{l}0.326^{* * *} \\
(0.111)\end{array}$ & $\begin{array}{l}3.354^{* * *} \\
(0.466)\end{array}$ & $\begin{array}{l}0.901^{* * *} \\
(0.018)\end{array}$ & $\begin{array}{l}5.628^{* * *} \\
(0.939)\end{array}$ & $\begin{array}{l}J=7.63, X^{2}(16) \\
p \text {-value }=0.959\end{array}$ & 0.249 \\
\hline Canada & $\begin{array}{c}0.088 \\
(0.138)\end{array}$ & $\begin{array}{l}1.072^{* * *} \\
(0.173)\end{array}$ & $\begin{array}{l}0.851^{* * *} \\
(0.016)\end{array}$ & $\begin{array}{l}3.819 * * * \\
(0.396)\end{array}$ & $\begin{array}{l}J=8.47, \chi^{2}(16) \\
p \text {-value }=0.934\end{array}$ & 0.377 \\
\hline Chile & $\begin{array}{l}-0.163^{* *} \\
(0.083)\end{array}$ & $\begin{array}{l}0.904^{* * *} \\
(0.105)\end{array}$ & $\begin{array}{l}0.758^{* * *} \\
(0.036)\end{array}$ & $\begin{array}{l}5.509^{* * *} \\
(0.424)\end{array}$ & $\begin{array}{l}J=6.81, \chi^{2}(16) \\
p \text {-value }=0.977\end{array}$ & 0.328 \\
\hline Czech Republic & $\begin{array}{l}1.078^{* * *} \\
(0.129)\end{array}$ & $\begin{array}{l}1.985^{* * *} \\
(0.485)\end{array}$ & $\begin{array}{l}0.942^{* * *} \\
(0.008)\end{array}$ & $\begin{array}{l}-0.123 \\
(0.583)\end{array}$ & $\begin{array}{l}J=7.46, \chi^{2}(16) \\
p \text {-value }=0.963\end{array}$ & 0.490 \\
\hline Denmark & $\begin{array}{c}0.195 \\
(0.538)\end{array}$ & $\begin{array}{l}0.677 \\
(0.620)\end{array}$ & $\begin{array}{l}0.976^{* * *} \\
(0.008)\end{array}$ & $\begin{array}{l}4.208^{* *} \\
(1.769)\end{array}$ & $\begin{array}{l}J=10.68, \chi^{2}(16) \\
p \text {-value }=0.829\end{array}$ & 0.390 \\
\hline Germany & $\begin{array}{c}0.394 \\
(0.311)\end{array}$ & $\begin{array}{l}0.678^{* * *} \\
(0.159)\end{array}$ & $\begin{array}{l}0.887^{* * *} \\
(0.022)\end{array}$ & $\begin{array}{l}3.470^{* * *} \\
(0.863)\end{array}$ & $\begin{array}{l}J=10.10, \chi^{2}(16) \\
p \text {-value }=0.862\end{array}$ & 0.220 \\
\hline Hungary & $\begin{array}{l}0.531^{* * *} \\
(0.075)\end{array}$ & $\begin{array}{c}-2.010^{*} \\
(1.157)\end{array}$ & $\begin{array}{l}0.890^{* * *} \\
(0.010)\end{array}$ & $\begin{array}{l}5.877^{* * *} \\
(0.600)\end{array}$ & $\begin{array}{l}J=7.82, \chi^{2}(16) \\
p \text {-value }=0.954\end{array}$ & 0.567 \\
\hline Iceland & $\begin{array}{l}1.004^{* * *} \\
(0.287)\end{array}$ & $\begin{array}{l}0.574^{*} \\
(0.333)\end{array}$ & $\begin{array}{l}0.942^{* * *} \\
(0.015)\end{array}$ & $\begin{array}{l}6.493^{* * *} \\
(1.004)\end{array}$ & $\begin{array}{l}J=7.49, \chi^{2}(16) \\
p \text {-value }=0.963\end{array}$ & 0.338 \\
\hline India & $\begin{array}{l}-0.165^{* * *} \\
(0.027)\end{array}$ & $\begin{array}{l}0.281^{* * *} \\
(0.037)\end{array}$ & $\begin{array}{l}0.823^{* * *} \\
(0.013)\end{array}$ & $\begin{array}{l}6.931^{* * *} \\
(0.157)\end{array}$ & $\begin{array}{l}J=6.21, x^{2}(16) \\
p \text {-value }=0.986\end{array}$ & 0.146 \\
\hline Indonesia & $\begin{array}{l}0.876^{* * *} \\
(0.334)\end{array}$ & $\begin{array}{l}-0.735^{* * *} \\
(0.268)\end{array}$ & $\begin{array}{l}0.788^{* * *} \\
(0.052)\end{array}$ & $\begin{array}{c}5.307^{*} \\
(3.101)\end{array}$ & $\begin{array}{l}J=6.72, X^{2}(16) \\
p \text {-value }=0.978\end{array}$ & 0.299 \\
\hline Israel & $\begin{array}{c}-1.543 \\
(1.247)\end{array}$ & $\begin{array}{c}-1.218 \\
(0.956)\end{array}$ & $\begin{array}{l}0.962^{* * *} \\
(0.020)\end{array}$ & $\begin{array}{l}8.186^{* * *} \\
(2.785)\end{array}$ & $\begin{array}{l}J=7.97, x^{2}(16) \\
p \text {-value }=0.950\end{array}$ & 0.334 \\
\hline Italy & $\begin{array}{l}1.244^{* * *} \\
(0.214)\end{array}$ & $\begin{array}{l}2.031^{* * *} \\
(0.766)\end{array}$ & $\begin{array}{l}0.915^{* * *} \\
(0.030)\end{array}$ & $\begin{array}{c}2.844 \\
(1.754)\end{array}$ & $\begin{array}{l}J=10.37, \chi^{2}(16) \\
p \text {-value }=0.847\end{array}$ & 0.205 \\
\hline Japan & $\begin{array}{l}1.466^{* * *} \\
(0.181)\end{array}$ & $\begin{array}{l}-0.257^{* *} \\
(0.114)\end{array}$ & $\begin{array}{l}0.919^{* * *} \\
(0.013)\end{array}$ & $\begin{array}{l}1.619^{* * *} \\
(0.225)\end{array}$ & $\begin{array}{l}J=11.43, \chi^{2}(16) \\
p \text {-value }=0.782\end{array}$ & 0.115 \\
\hline Latvia & $\begin{array}{l}0.0637^{* * *} \\
(0.016)\end{array}$ & $\begin{array}{c}0.0221 \\
(0.039)\end{array}$ & $\begin{array}{l}0.753^{* * *} \\
(0.021)\end{array}$ & $\begin{array}{l}3.254^{* * *} \\
(0.133)\end{array}$ & $\begin{array}{l}J=8.12, \chi^{2}(16) \\
p \text {-value }=0.945\end{array}$ & 0.384 \\
\hline Netherlands & $\begin{array}{l}0.735^{* * *} \\
(0.082)\end{array}$ & $\begin{array}{l}1.248^{* * *} \\
(0.203)\end{array}$ & $\begin{array}{l}0.841^{* * *} \\
(0.024)\end{array}$ & $\begin{array}{l}4.726^{* * *} \\
(0.232)\end{array}$ & $\begin{array}{l}J=6.76, X^{2}(16) \\
p \text {-value }=0.978\end{array}$ & 0.548 \\
\hline Norway & $\begin{array}{c}-0.629 \\
(0.471)\end{array}$ & $\begin{array}{l}1.927^{* *} \\
(0.770)\end{array}$ & $\begin{array}{l}0.970^{* * *} \\
(0.011)\end{array}$ & $\begin{array}{l}10.25^{* * *} \\
(2.216)\end{array}$ & $\begin{array}{l}J=11.73, \chi^{2}(16) \\
p \text {-value }=0.762\end{array}$ & 0.396 \\
\hline Poland & $\begin{array}{l}-0.427^{* * *} \\
(0.111)\end{array}$ & $\begin{array}{l}6.484^{* * *} \\
(0.526)\end{array}$ & $\begin{array}{l}0.855^{* * *} \\
(0.014)\end{array}$ & $\begin{array}{l}7.930^{* * *} \\
(0.438)\end{array}$ & $\begin{array}{l}J=6.73, X^{2}(16) \\
p \text {-value }=0.978\end{array}$ & 0.304 \\
\hline Portugal & $\begin{array}{l}1.223^{* * *} \\
(0.253)\end{array}$ & $\begin{array}{l}0.964^{* *} \\
(0.435)\end{array}$ & $\begin{array}{l}0.920^{* * *} \\
(0.034)\end{array}$ & $\begin{array}{l}-1.327 \\
(3.639)\end{array}$ & $\begin{array}{l}J=8.38, X^{2}(16) \\
p \text {-value }=0.937\end{array}$ & 0.257 \\
\hline Slovenia & $\begin{array}{l}1.267^{* * *} \\
(0.110)\end{array}$ & $\begin{array}{c}0.621 \\
(0.491)\end{array}$ & $\begin{array}{l}0.874^{* * *} \\
(0.018)\end{array}$ & $\begin{array}{l}1.444^{*} \\
(0.737)\end{array}$ & $\begin{array}{l}J=6.88, \chi^{2}(16) \\
p \text {-value }=0.976\end{array}$ & 0.521 \\
\hline South Africa & $\begin{array}{c}0.354 \\
(0.253)\end{array}$ & $\begin{array}{l}1.006^{* * *} \\
(0.327)\end{array}$ & $\begin{array}{l}0.897^{* * *} \\
(0.022)\end{array}$ & $\begin{array}{l}9.633^{* * *} \\
(2.771)\end{array}$ & $\begin{array}{l}J=11.98, \chi^{2}(16) \\
p \text {-value }=0.745\end{array}$ & 0.260 \\
\hline Spain & $\begin{array}{l}1.672^{* * *} \\
(0.195)\end{array}$ & $\begin{array}{c}-0.205 \\
(0.145)\end{array}$ & $\begin{array}{l}0.822^{* * *} \\
(0.036)\end{array}$ & $\begin{array}{c}1.619 \\
(1.063)\end{array}$ & $\begin{array}{l}J=9.30, x^{2}(16) \\
p \text {-value }=0.901\end{array}$ & 0.196 \\
\hline Switzerland & $\begin{array}{l}0.614^{* * *} \\
(0.172)\end{array}$ & $\begin{array}{l}0.494^{* * *} \\
(0.170)\end{array}$ & $\begin{array}{l}0.915^{* * *} \\
(0.012)\end{array}$ & $\begin{array}{l}1.860^{* * *} \\
(0.366)\end{array}$ & $\begin{array}{l}J=12.68, x^{2}(16) \\
p \text {-value }=0.696\end{array}$ & 0.463 \\
\hline United Kingdom & $\begin{array}{l}0.873^{* * *} \\
(0.337)\end{array}$ & $\begin{array}{c}0.903^{*} \\
(0.545)\end{array}$ & $\begin{array}{l}0.903^{* * *} \\
(0.022)\end{array}$ & $\begin{array}{l}3.846^{* * *} \\
(1.305)\end{array}$ & $\begin{array}{l}J=7.61, \chi^{2}(16) \\
p \text {-value }=0.960\end{array}$ & 0.235 \\
\hline United States & $\begin{array}{l}1.354^{* *} \\
(0.584)\end{array}$ & $\begin{array}{l}0.621^{* * *} \\
(0.228)\end{array}$ & $\begin{array}{l}0.932^{* * *} \\
(0.016)\end{array}$ & $\begin{array}{c}1.707 \\
(1.610)\end{array}$ & $\begin{array}{l}J=10.83, \chi^{2}(16) \\
p \text {-value }=0.820\end{array}$ & 0.093 \\
\hline
\end{tabular}

NOTE: * **, and ${ }^{* * *}$ denote 10 percent, 5 percent, and 1 percent statistical significance, respectively. The coefficients on expected inflation, the output gap, and lagged interest rates correspond to $\beta, \gamma$, and $\rho_{1}+\rho_{2}$, respectively, from equation (4). The constant corresponds to $\bar{R}-\beta \pi^{*}$.

Standard errors are in parentheses. 
Therefore, throughout the rest of the article, I interpret the Taylor rule coefficients as moments that characterize salient features of monetary policy in each country rather than as structural parameters.

5.1.2 Cross-Country Estimates. I now examine salient features of my estimated Taylor rule coefficients across countries (Table 2). First, I find that there is substantial heterogeneity across countries in the Taylor rule coefficient on expected inflation. This coefficient is estimated to be negative for three countries (Chile, India, and Poland), not statistically different from zero $\underline{12}$ for seven countries (Austria, Canada, Denmark, Germany, Israel, Norway, and South Africa), statistically higher than zero but lower than 1 for seven countries (Bolivia, Hungary, Indonesia, Latvia, the Netherlands, Switzerland, and the United Kingdom), and higher than 1 for nine countries (Australia, the Czech Republic, Iceland, Italy, Japan, Portugal, Slovenia, Spain, and the United States). $\underline{13}$

Second, I find that there is a similar degree of heterogeneity across countries in the Taylor rule coefficient on the output gap. This coefficient is estimated to be negative for three countries (Hungary, Indonesia, and Japan), not statistically different from zero for six countries (Australia, Denmark, Israel, Latvia, Slovenia, and Spain), statistically higher than zero but lower than 1 for eight countries (Chile, Germany, Iceland, India, Portugal, Switzerland, the United Kingdom, and the United States), and higher than 1 for nine countries (Austria, Bolivia, Canada, the Czech Republic, Italy, the Netherlands, Norway, Poland, and South Africa).

Third, I find that the sum of the coefficients on lagged interest rates is statistically significant for all countries, suggesting that all countries engage in some degree of nominal interest rate smoothing. Therefore, while countries differ in the response to changes in expected inflation and the output gap, in all cases lagged interest rates are an important factor in determining current interest rates.

Finally, the last column of Table 2 reports the average degree of trade openness, measured through the exports-to-GDP ratio across the 26 countries under analysis. I find that there is substantial heterogeneity in the degree of trade openness across these countries, ranging from relatively closed economies such as the United States and Japan, with exports-to-GDP ratios equal to 0.093 and 0.115 , respectively, to relatively open economies such as Hungary, the Netherlands, and Slovenia, with exports-to-GDP ratios equal to $0.567,0.548$, and 0.521 , respectively.

\subsection{Taylor Rule Coefficients and Trade Openness}

I now ask, to what extent do open economies conduct monetary policy differently from closed economies? To answer this question, I examine the relationship between the crosscountry Taylor rule coefficients reported in Table 2 and the countries' degree of openness to international trade.

5.2.1 Expected Inflation. The top panel of Table 3 reports the results of regressing the country-specific Taylor rule coefficients on each country's aggregate exports-to-GDP ratio. The first two columns of the table report the results from conducting the analysis using the expected- inflation Taylor rule coefficients for all countries regardless of the degree of statistical significance obtained in the previous section. The last two columns of this table report the 
Table 3

Monetary Policy and Trade Openness: The Baseline Taylor Rule

\begin{tabular}{|c|c|c|c|c|}
\hline & \multicolumn{2}{|c|}{ All countries } & \multicolumn{2}{|c|}{$\begin{array}{c}\text { With Taylor rule coefficient } \\
\text { significant at } 10 \%\end{array}$} \\
\hline & $(1)$ & $(2)$ & (3) & $(4)$ \\
\hline \multicolumn{5}{|c|}{ Dependent Variable: The Taylor Rule Coefficient on Expected Inflation } \\
\hline $\mathrm{X} / \mathrm{GDP}$ & $\begin{array}{c}-1.284 \\
(1.033)\end{array}$ & $\begin{array}{c}-1.471 \\
(0.955)\end{array}$ & $\begin{array}{c}-0.895 \\
(0.826)\end{array}$ & $\begin{array}{c}-1.182^{* *} \\
(0.529)\end{array}$ \\
\hline GDP per capita & & $\begin{array}{c}0.184 \\
(0.159)\end{array}$ & & $\begin{array}{l}0.434^{* * * *} \\
(0.115)\end{array}$ \\
\hline Constant & $\begin{array}{l}0.947^{* *} \\
(0.358)\end{array}$ & $\begin{array}{c}-0.799 \\
(1.523)\end{array}$ & $\begin{array}{l}1.071^{* * *} \\
(0.333)\end{array}$ & $\begin{array}{l}-3.034^{* *} \\
(1.165)\end{array}$ \\
\hline$R^{2}$ & 0.049 & 0.082 & 0.046 & 0.372 \\
\hline No. of countries & 26 & 26 & 19 & 19 \\
\hline \multicolumn{5}{|c|}{ Dependent Variable: The Taylor Rule Coefficient on the Output Gap } \\
\hline $\mathrm{X} / \mathrm{GDP}$ & $\begin{array}{l}-0.806 \\
(2.039)\end{array}$ & $\begin{array}{c}-0.674 \\
(2.134)\end{array}$ & $\begin{array}{l}-0.963 \\
(2.745)\end{array}$ & $\begin{array}{l}-0.91 \\
(2.943)\end{array}$ \\
\hline GDP per capita & & $\begin{array}{l}-0.13 \\
(0.408)\end{array}$ & & $\begin{array}{c}-0.0396 \\
(0.437)\end{array}$ \\
\hline Constant & $\begin{array}{c}1.142 \\
(0.682)\end{array}$ & $\begin{array}{c}2.374 \\
(4.075)\end{array}$ & $\begin{array}{c}1.428 \\
(0.877)\end{array}$ & $\begin{array}{c}1.796 \\
(4.261)\end{array}$ \\
\hline$R^{2}$ & 0.005 & 0.009 & 0.006 & 0.006 \\
\hline No. of countries & 26 & 26 & 20 & 20 \\
\hline \multicolumn{5}{|c|}{ Dependent Variable: The Taylor Rule Coefficient on Interest Rate Lags } \\
\hline $\mathrm{X} / \mathrm{GDP}$ & $\begin{array}{l}0.000228 \\
(0.0668)\end{array}$ & $\begin{array}{l}-0.0434 \\
(0.0546)\end{array}$ & $\begin{array}{l}0.000228 \\
(0.0668)\end{array}$ & $\begin{array}{l}-0.0434 \\
(0.0546)\end{array}$ \\
\hline GDP per capita & & $\begin{array}{l}0.0428^{* * *} \\
(0.0139)\end{array}$ & & $\begin{array}{l}0.0428^{* * *} \\
(0.0139)\end{array}$ \\
\hline Constant & $\begin{array}{l}0.886^{* * *} \\
(0.0220)\end{array}$ & $\begin{array}{l}0.482^{* * *} \\
(0.140)\end{array}$ & $\begin{array}{l}0.886^{* * *} \\
(0.0220)\end{array}$ & $\begin{array}{l}0.482^{* * *} \\
(0.140)\end{array}$ \\
\hline$R^{2}$ & 0.000 & 0.284 & 0.000 & 0.284 \\
\hline No. of countries & 26 & 26 & 26 & 26 \\
\hline
\end{tabular}

results when restricting attention to the subset of expected-inflation Taylor rule coefficients that are statistically significant at the 10 percent level. $\underline{14}$

I find that all specifications imply that there is a negative relationship between the degree of a country's trade openness and the Taylor rule coefficient on expected inflation: In open economies the nominal interest rate responds relatively less to changes in inflation. This relationship, however, is only statistically significant when one controls for GDP per capita while 
restricting attention to countries with significant Taylor rule coefficients. That is, among the set of countries that respond to changes in expected inflation, they seem to respond relatively less if they are open.

As observed in Table 2, the Taylor rule coefficient on expected inflation is not statistically significant for all countries. This is because either their Taylor rule coefficients are very close to zero or because the coefficients are estimated with a significant amount of error. Therefore, in columns 3 and 4, I restrict attention to countries in which the Taylor rule coefficients are significant at the 10 percent level.

Yet, only once I control for the countries' level of GDP per capita does the relationship between trade openness and the Taylor rule coefficient on expect inflation become significant. This is not necessarily very surprising, given developed economies are simultaneously more likely to be open as well as to be inflation targeters in their conduct of monetary policy.

To quantify the economic importance of this relationship, consider the average Taylor rule coefficient on expected inflation is equal to 0.54 . Then, changing the aggregate exportsto-GDP ratio from its lowest to highest value across countries (from 0.093 to 0.567 ) is associated with a decrease in the value of the Taylor rule coefficient equal to 0.56 . This evidence suggests that open economies assign a lower weight on expected inflation when conducting monetary policy, a relationship that is both statistically and economically significant.

5.2.2 Output Gap. The middle panel of Table 3 reports the results of regressing the country-specific output-gap Taylor rule coefficients on each country's aggregate exports-toGDP ratio. I find that there is no systematic relationship between the degree of a country's trade openness and the weight it assigns to changes in the output gap for the conduct of monetary policy. This finding is robust to restricting attention to Taylor rule coefficients that are statistically significant at the 10 percent level as well as to controlling for GDP per capita (see columns 1 to 4 ). In all cases, the relationship between trade openness and the weight on the output gap is negative, but the degree of error is substantial, making these coefficients statistically insignificant. This evidence suggests that monetary policy in open and closed economies responds similarly to changes in the output gap.

5.2.3 Lagged Interest Rates. Finally, the bottom panel of Table 3 reports the results of regressing the country-specific sum of the interest rate lags of the Taylor rule on each country's aggregate exports-to-GDP ratio. As with the output gap, I find that there is no systematic relationship between the degree of a country's trade openness and the extent to which that country smooths its interest rate adjustments over time. This finding is robust to restricting attention to Taylor rule coefficients that are statistically significant at the 10 percent level as well as to controlling for GDP per capita (see columns 1 to 4). Yet, what I do find is that richer economies smooth their nominal interest rate adjustments relatively more than poorer ones, suggesting that richer economies conduct their monetary policy decisions in a more predictable way.

\section{TAYLOR RULE WITH REAL EXCHANGE RATE}

The evidence presented in the previous section suggests that monetary policy in open economies is conducted differently from monetary policy in closed economies, but only along 
certain dimensions. In particular, while open economies typically assign a lower weight to changes in expected inflation, they respond to changes in the output gap to a similar extent as closed economies do.

I now examine whether, in addition to inflation, open economies also respond differently to changes in other variables not included in the baseline specification of the Taylor rule. Following previous studies from the literature, in this article I restrict attention to the real exchange rate as an additional variable that central banks in open economies may respond to when conducting monetary policy.

\subsection{Taylor Rule Coefficients}

As in the previous section, I begin by estimating a Taylor rule for each of the countries in the sample. In this section, however, I extend the Taylor rule by including the real exchange rate as an additional variable that nominal interest rates may respond to. $\frac{15}{}$ In particular, I compute the real exchange rate variable that nominal interest rates respond to as the log difference of the real exchange rate from its country-specific quadratic trend. $\frac{16}{}$ Table 4 presents the estimated Taylor rule coefficients corresponding to this extended specification of the Taylor rule.

I find that there is significant heterogeneity in the estimated Taylor rule coefficients on the real exchange rate. This coefficient is estimated to be negative for eight countries (the Czech Republic, Germany, Hungary, Indonesia, Japan, the Netherlands, Poland, and Switzerland), not statistically different from zero for 13 countries (Australia, Austria, Chile, Denmark, Iceland, India, Israel, Italy, Norway, Slovenia, South Africa, the United Kingdom, and the United States), and statistically higher than zero for five countries (Bolivia, Canada, Latvia, Portugal, and Spain). $\underline{.17}$

Moreover, I also find that including the real exchange rate as an additional variable in the Taylor rule significantly affects the estimated coefficients on expected inflation and the output gap, as can be readily observed by comparing Tables 2 and 4 .

These findings suggest that the real exchange rate is a variable that many central banks across the world might respond to when executing monetary policy decisions, even if they sometimes respond to it to different extents and in qualitatively different ways.

\subsection{Taylor Rule Coefficients and Trade Openness}

I now ask, to what extent do open economies conduct monetary policy differently from closed economies once the real exchange is included as an additional variable in the Taylor rule? To answer this question, I examine the relationship between the cross-country Taylor rule coefficients reported in Table 4 and the countries' degree of openness to international trade.

6.2.1 Expected Inflation. The top panel of Table 5 reports the results of regressing the country-specific expected-inflation Taylor rule coefficients on each country's aggregate exports-to-GDP ratio. I find that, while the relationship between trade openness and the weight on expected inflation is negative, as in the previous section, this relationship is statistically insignificant in all the specifications considered. In particular, note that I no longer find that open economies assign a lower weight on expected inflation once I restrict attention 


\section{Table 4}

\section{Taylor Rule Coefficients: The Baseline Taylor Rule}

Taylor rule coefficients

\begin{tabular}{|c|c|c|c|c|c|c|c|}
\hline Country & $\begin{array}{l}\text { Expected } \\
\text { inflation }\end{array}$ & $\begin{array}{l}\text { Output } \\
\text { gap }\end{array}$ & $\begin{array}{c}\text { Real } \\
\text { exchange rate }\end{array}$ & $\begin{array}{c}\text { Lagged } \\
\text { interest rates }\end{array}$ & Constant & $\begin{array}{c}\text { Overidentification } \\
\text { test }\end{array}$ & $\begin{array}{c}\text { Trade openness } \\
\text { X/GDP }\end{array}$ \\
\hline Australia & $\begin{array}{l}1.569^{* * *} \\
(0.286)\end{array}$ & $\begin{array}{c}0.614 \\
(0.460)\end{array}$ & $\begin{array}{c}-0.0799 \\
(0.148)\end{array}$ & $\begin{array}{l}0.898^{* * *} \\
(0.015)\end{array}$ & $\begin{array}{c}1.330 \\
(1.342)\end{array}$ & $\begin{array}{l}J=11.61, X^{2}(15) \\
p \text {-value }=0.708\end{array}$ & 0.172 \\
\hline Austria & $\begin{array}{c}-0.0278 \\
(0.342)\end{array}$ & $\begin{array}{l}1.020^{* * * *} \\
(0.283)\end{array}$ & $\begin{array}{l}-0.415 \\
(0.337)\end{array}$ & $\begin{array}{l}0.932^{* * *} \\
(0.020)\end{array}$ & $\begin{array}{l}4.537^{* * *} \\
(1.060)\end{array}$ & $\begin{array}{l}J=10.65, x^{2}(15) \\
p \text {-value }=0.777\end{array}$ & 0.339 \\
\hline Bolivia & $\begin{array}{l}0.208^{*} \\
(0.121)\end{array}$ & $\begin{array}{l}2.408^{* * * *} \\
(0.498)\end{array}$ & $\begin{array}{l}1.173^{* * *} \\
(0.272)\end{array}$ & $\begin{array}{l}0.892^{* * *} \\
(0.025)\end{array}$ & $\begin{array}{l}6.457^{* * *} \\
(1.355)\end{array}$ & $\begin{array}{l}J=7.55, X^{2}(15) \\
p \text {-value }=0.951\end{array}$ & 0.249 \\
\hline Canada & $\begin{array}{c}0.0427 \\
(0.132)\end{array}$ & $\begin{array}{l}1.260^{* * * *} \\
(0.211)\end{array}$ & $\begin{array}{l}0.186^{* * *} \\
(0.066)\end{array}$ & $\begin{array}{l}0.846^{* * *} \\
(0.021)\end{array}$ & $\begin{array}{l}3.781^{* * *} \\
(0.327)\end{array}$ & $\begin{array}{l}J=8.33, X^{2}(15) \\
p \text {-value }=0.910\end{array}$ & 0.377 \\
\hline Chile & $\begin{array}{l}-0.178^{*} \\
(0.095)\end{array}$ & $\begin{array}{l}1.404^{* * *} \\
(0.250)\end{array}$ & $\begin{array}{l}-0.186 \\
(0.132)\end{array}$ & $\begin{array}{l}0.799 * * * \\
(0.032)\end{array}$ & $\begin{array}{l}5.376^{* * *} \\
(0.530)\end{array}$ & $\begin{array}{c}J=6.59, X^{2}(15) \\
p \text {-value }=0.968\end{array}$ & 0.328 \\
\hline Czech Republic & $\begin{array}{l}0.960^{* * *} \\
(0.153)\end{array}$ & $\begin{array}{l}1.691^{* *} \\
(0.843)\end{array}$ & $\begin{array}{l}-0.984^{* * *} \\
(0.298)\end{array}$ & $\begin{array}{l}0.951^{* * *} \\
(0.008)\end{array}$ & $\begin{array}{l}-0.349 \\
(0.935)\end{array}$ & $\begin{array}{l}J=7.81, X^{2}(15) \\
p \text {-value }=0.931\end{array}$ & 0.490 \\
\hline Denmark & $\begin{array}{l}0.0876 \\
(0.586)\end{array}$ & $\begin{array}{c}0.755 \\
(0.755)\end{array}$ & $\begin{array}{l}-0.705 \\
(0.552)\end{array}$ & $\begin{array}{l}0.976^{* * *} \\
(0.010)\end{array}$ & $\begin{array}{l}4.605^{* *} \\
(1.801)\end{array}$ & $\begin{array}{l}J=9.89, X^{2}(15) \\
p \text {-value }=0.827\end{array}$ & 0.390 \\
\hline Germany & $\begin{array}{c}0.176 \\
(0.373)\end{array}$ & $\begin{array}{l}0.810^{* * * *} \\
(0.262)\end{array}$ & $\begin{array}{l}-0.355^{* *} \\
(0.159)\end{array}$ & $\begin{array}{l}0.916^{* * *} \\
(0.029)\end{array}$ & $\begin{array}{l}3.787^{* * *} \\
(0.864)\end{array}$ & $\begin{array}{l}J=9.09, X^{2}(15) \\
p \text {-value }=0.873\end{array}$ & 0.220 \\
\hline Hungary & $\begin{array}{l}0.635^{* * *} \\
(0.116)\end{array}$ & $\begin{array}{c}0.364 \\
(1.616)\end{array}$ & $\begin{array}{l}-0.654^{* * *} \\
(0.191)\end{array}$ & $\begin{array}{l}0.913^{* * *} \\
(0.013)\end{array}$ & $\begin{array}{l}4.182^{* * *} \\
(1.020)\end{array}$ & $\begin{array}{l}J=7.51, X^{2}(15) \\
p \text {-value }=0.942\end{array}$ & 0.567 \\
\hline Iceland & $\begin{array}{l}1.294^{* *} \\
(0.503)\end{array}$ & $\begin{array}{c}0.481 \\
(0.383)\end{array}$ & $\begin{array}{c}0.270 \\
(0.212)\end{array}$ & $\begin{array}{l}0.953^{* * *} \\
(0.018)\end{array}$ & $\begin{array}{l}5.767^{* * *} \\
(0.212)\end{array}$ & $\begin{array}{l}J=7.00, X^{2}(15) \\
p \text {-value }=0.958\end{array}$ & 0.338 \\
\hline India & $\begin{array}{l}-0.184^{* * *} \\
(0.039)\end{array}$ & $\begin{array}{l}0.256^{* * *} \\
(0.060)\end{array}$ & $\begin{array}{c}0.0546 \\
(0.071)\end{array}$ & $\begin{array}{l}0.820^{* * *} \\
(0.012)\end{array}$ & $\begin{array}{l}7.042^{* * *} \\
(0.237)\end{array}$ & $\begin{array}{l}J=5.95, X^{2}(15) \\
p \text {-value }=0.981\end{array}$ & 0.146 \\
\hline Indonesia & $\begin{array}{l}0.266^{* * *} \\
(0.092)\end{array}$ & $\begin{array}{l}1.101^{* *} \\
(0.441)\end{array}$ & $\begin{array}{l}-0.874^{* * *} \\
(0.227)\end{array}$ & $\begin{array}{l}0.733^{* * *} \\
(0.032)\end{array}$ & $\begin{array}{l}13.38^{* * *} \\
(1.748)\end{array}$ & $\begin{array}{l}J=8.83, X^{2}(15) \\
p \text {-value }=0.886\end{array}$ & 0.299 \\
\hline Israel & $\begin{array}{l}-1.245 \\
(1.287)\end{array}$ & $\begin{array}{l}-0.690 \\
(1.241)\end{array}$ & $\begin{array}{c}-0.410 \\
(0.610)\end{array}$ & $\begin{array}{l}0.959^{* * *} \\
(0.023)\end{array}$ & $\begin{array}{l}7.569^{* *} \\
(3.116)\end{array}$ & $\begin{array}{l}J=7.94, X^{2}(15) \\
p \text {-value }=0.926\end{array}$ & 0.334 \\
\hline Italy & $\begin{array}{l}1.336^{* * *} \\
(0.239)\end{array}$ & $\begin{array}{l}2.717^{* *} \\
(1.222)\end{array}$ & $\begin{array}{l}-0.203 \\
(0.222)\end{array}$ & $\begin{array}{l}0.927^{* * *} \\
(0.029)\end{array}$ & $\begin{array}{c}1.959 \\
(2.000)\end{array}$ & $\begin{array}{l}J=10.10, X^{2}(15) \\
p \text {-value }=0.814\end{array}$ & 0.205 \\
\hline Japan & $\begin{array}{l}1.309^{* * *} \\
(0.194)\end{array}$ & $\begin{array}{l}-0.220^{* *} \\
(0.110)\end{array}$ & $\begin{array}{l}-0.0939^{* *} \\
(0.041)\end{array}$ & $\begin{array}{l}0.916^{* * *} \\
(0.015)\end{array}$ & $\begin{array}{l}1.458^{* * *} \\
(0.304)\end{array}$ & $\begin{array}{l}J=11.15, x^{2}(15) \\
p \text {-value }=0.742\end{array}$ & 0.115 \\
\hline Latvia & $\begin{array}{l}0.0686^{* * *} \\
(0.019)\end{array}$ & $\begin{array}{c}0.0801 \\
(0.058)\end{array}$ & $\begin{array}{l}0.128^{* * *} \\
(0.022)\end{array}$ & $\begin{array}{l}0.759^{* * *} \\
(0.020)\end{array}$ & $\begin{array}{l}3.262^{* * *} \\
(0.148)\end{array}$ & $\begin{array}{l}J=7.38, X^{2}(15) \\
p \text {-value }=0.946\end{array}$ & 0.384 \\
\hline Netherlands & $\begin{array}{l}0.554^{* * *} \\
(0.082)\end{array}$ & $\begin{array}{l}1.221^{* * * *} \\
(0.183)\end{array}$ & $\begin{array}{l}-0.346^{* * *} \\
(0.065)\end{array}$ & $\begin{array}{l}0.828^{* * *} \\
(0.022)\end{array}$ & $\begin{array}{l}4.929 * * * \\
(0.190)\end{array}$ & $\begin{array}{l}J=6.68, X^{2}(15) \\
p \text {-value }=0.966\end{array}$ & 0.548 \\
\hline Norway & $\begin{array}{l}-0.651 \\
(0.516)\end{array}$ & $\begin{array}{l}1.939 * * \\
(0.841)\end{array}$ & $\begin{array}{c}-0.178 \\
(0.716)\end{array}$ & $\begin{array}{l}0.972^{* * *} \\
(0.014)\end{array}$ & $\begin{array}{l}10.30^{* * *} \\
(2.380)\end{array}$ & $\begin{array}{l}J=11.69, x^{2}(15) \\
p \text {-value }=0.703\end{array}$ & 0.396 \\
\hline Poland & $\begin{array}{l}-1.803^{* * *} \\
(0.407)\end{array}$ & $\begin{array}{l}10.91^{* * *} \\
(1.449)\end{array}$ & $\begin{array}{l}-0.653^{* * *} \\
(0.177)\end{array}$ & $\begin{array}{l}0.898^{* * *} \\
(0.016)\end{array}$ & $\begin{array}{l}10.08^{* * *} \\
(0.894)\end{array}$ & $\begin{array}{l}J=6.39, X^{2}(15) \\
p \text {-value }=0.972\end{array}$ & 0.304 \\
\hline Portugal & $\begin{array}{l}0.985^{* * *} \\
(0.136)\end{array}$ & $\begin{array}{c}0.313 \\
(0.215)\end{array}$ & $\begin{array}{l}0.421^{* * *} \\
(0.158)\end{array}$ & $\begin{array}{l}0.848^{* * *} \\
(0.055)\end{array}$ & $\begin{array}{c}2.792^{*} \\
(1.627)\end{array}$ & $\begin{array}{l}J=7.30, X^{2}(15) \\
p \text {-value }=0.949\end{array}$ & 0.257 \\
\hline Slovenia & $\begin{array}{l}1.267^{* * *} \\
(0.111)\end{array}$ & $\begin{array}{c}0.578 \\
(0.619)\end{array}$ & $\begin{array}{l}-0.00940 \\
(0.152)\end{array}$ & $\begin{array}{l}0.873^{* * *} \\
(0.019)\end{array}$ & $\begin{array}{l}1.454^{* *} \\
(0.737)\end{array}$ & $\begin{array}{l}J=6.86, X^{2}(15) \\
p \text {-value }=0.962\end{array}$ & 0.521 \\
\hline South Africa & $\begin{array}{c}0.239 \\
(0.294)\end{array}$ & $\begin{array}{l}1.038^{* * *} \\
(0.383)\end{array}$ & $\begin{array}{l}-0.110 \\
(0.153)\end{array}$ & $\begin{array}{l}0.904^{* * *} \\
(0.027)\end{array}$ & $\begin{array}{l}10.84^{* * *} \\
(3.143)\end{array}$ & $\begin{array}{c}J=11.22, x^{2}(15) \\
p \text {-value }=0.74\end{array}$ & 0.260 \\
\hline Spain & $\begin{array}{l}1.528^{* * *} \\
(0.238)\end{array}$ & $\begin{array}{l}-2.405^{* * *} \\
(0.462)\end{array}$ & $\begin{array}{l}1.154^{* * *} \\
(0.220)\end{array}$ & $\begin{array}{l}0.832^{* * *} \\
(0.030)\end{array}$ & $\begin{array}{c}2.126^{*} \\
(1.148)\end{array}$ & $\begin{array}{l}J=8.53, X^{2}(15) \\
p \text {-value }=0.901\end{array}$ & 0.196 \\
\hline Switzerland & $\begin{array}{l}0.925^{* * *} \\
(0.203)\end{array}$ & $\begin{array}{c}0.197 \\
(0.148)\end{array}$ & $\begin{array}{l}-0.489^{* * *} \\
(0.138)\end{array}$ & $\begin{array}{l}0.908^{* * *} \\
(0.018)\end{array}$ & $\begin{array}{l}1.529^{* * *} \\
(0.517)\end{array}$ & $\begin{array}{l}J=9.53, X^{2}(15) \\
p \text {-value }=0.848\end{array}$ & 0.463 \\
\hline United Kingdom & $\begin{array}{l}0.846^{* *} \\
(0.343)\end{array}$ & $\begin{array}{c}0.909 \\
(0.579)\end{array}$ & $\begin{array}{l}0.00500 \\
(0.123)\end{array}$ & $\begin{array}{l}0.905^{* * *} \\
(0.022)\end{array}$ & $\begin{array}{l}3.950^{* * *} \\
(1.326)\end{array}$ & $\begin{array}{l}J=7.68, X^{2}(15) \\
p \text {-value }=0.936\end{array}$ & 0.235 \\
\hline United States & $\begin{array}{c}1.701 \\
(1.035)\end{array}$ & $\begin{array}{c}0.491 \\
(0.359)\end{array}$ & $\begin{array}{c}0.0587 \\
(0.059)\end{array}$ & $\begin{array}{l}0.931^{* * *} \\
(0.016)\end{array}$ & $\begin{array}{c}0.846 \\
(2.688)\end{array}$ & $\begin{array}{l}J=10.73, X^{2}(15) \\
p \text {-value }=0.772\end{array}$ & 0.093 \\
\hline
\end{tabular}

NOTE: ${ }^{* * *}$, and ${ }^{* * *}$ denote 10 percent, 5 percent, and 1 percent statistical significance, respectively. The coefficients on expected inflation, the output gap, and lagged interest rates correspond to $\beta, \gamma$, and $\rho_{1}+\rho_{2}$, respectively, from equation (4). The constant corresponds to $\bar{R}-\beta \pi^{*}$. Standard errors are in parentheses. 


\section{Table 5}

Monetary Policy and Trade Openness: The Taylor Rule with the Real Exchange Rate

\begin{tabular}{|c|c|c|c|c|}
\hline & \multicolumn{2}{|c|}{ All countries } & \multicolumn{2}{|c|}{$\begin{array}{c}\text { With Taylor rule coefficient } \\
\text { significant at } 10 \%\end{array}$} \\
\hline & $(1)$ & $(2)$ & (3) & (4) \\
\hline \multicolumn{5}{|c|}{ Dependent Variable: The Taylor Rule Coefficient on Expected Inflation } \\
\hline $\mathrm{X} / \mathrm{GDP}$ & $\begin{array}{l}-1.200 \\
(1.163)\end{array}$ & $\begin{array}{l}-1.541 \\
(1.042)\end{array}$ & $\begin{array}{r}-0.332 \\
(0.992)\end{array}$ & $\begin{array}{l}-1.123 \\
(0.642)\end{array}$ \\
\hline GDP per capita & & $\begin{array}{l}0.335^{* *} \\
(0.140)\end{array}$ & & $\begin{array}{l}0.574^{* * *} \\
(0.0940)\end{array}$ \\
\hline Constant & $\begin{array}{l}0.837^{*} \\
(0.418)\end{array}$ & $\begin{array}{c}-2.331^{*} \\
(1.280)\end{array}$ & $\begin{array}{c}0.751 \\
(0.442)\end{array}$ & $\begin{array}{l}-4.509^{* * *} \\
(0.906)\end{array}$ \\
\hline$R^{2}$ & 0.033 & 0.118 & 0.003 & 0.302 \\
\hline No. of countries & 26 & 26 & 18 & 18 \\
\hline \multicolumn{5}{|c|}{ Dependent Variable: The Taylor Rule Coefficient on the Output Gap } \\
\hline $\mathrm{X} / \mathrm{GDP}$ & $\begin{array}{c}0.919 \\
(1.611)\end{array}$ & $\begin{array}{c}1.269 \\
(1.655)\end{array}$ & $\begin{array}{c}4.148 \\
(3.288)\end{array}$ & $\begin{array}{c}4.731 \\
(3.831)\end{array}$ \\
\hline GDP per capita & & $\begin{array}{l}-0.343 \\
(0.303)\end{array}$ & & $\begin{array}{l}-0.234 \\
(0.371)\end{array}$ \\
\hline Constant & $\begin{array}{c}0.834 \\
(0.790)\end{array}$ & $\begin{array}{l}4.080 \\
(3.256)\end{array}$ & $\begin{array}{c}0.440 \\
(1.291)\end{array}$ & $\begin{array}{c}2.505 \\
(3.072)\end{array}$ \\
\hline$R^{2}$ & 0.003 & 0.016 & 0.031 & 0.036 \\
\hline No. of countries & 26 & 26 & 15 & 15 \\
\hline
\end{tabular}

Dependent Variable: The Taylor Rule Coefficient on the Real Exchange Rate

\begin{tabular}{lcccc} 
X/GDP & $-1.630^{* * *}$ & $-1.548^{* * *}$ & $-2.480^{* * *}$ & $-2.348^{*}$ \\
& $(0.579)$ & $(0.558)$ & $(1.113)$ & $(1.083)$ \\
GDP per capita & & -0.0808 & & -0.122 \\
Constant & & $(0.175)$ & & $(0.356)$ \\
& 0.389 & 1.154 & 0.746 & 1.877 \\
$R^{2}$ & $(0.229)$ & $(1.765)$ & $(0.512)$ & $(3.494)$ \\
\hline No. of countries & 0.171 & 0.185 & 0.251 & 0.268 \\
\hline
\end{tabular}

Dependent Variable: The Taylor Rule Coefficient on Interest Rate Lags

\begin{tabular}{lcccc} 
X/GDP & 0.0109 & -0.0396 & 0.0109 & -0.0396 \\
& $(0.0732)$ & $(0.0648)$ & $(0.0732)$ & $(0.0648)$ \\
GDP per capita & & $0.0496^{* * *}$ & & $0.0496^{* * *}$ \\
& & $(0.0163)$ & & $(0.0163)$ \\
Constant & $0.885^{* * *}$ & $0.415^{* *}$ & $0.885^{* * *}$ & $0.415^{* *}$ \\
\hline$R^{2}$ & $(0.0241)$ & $(0.164)$ & $(0.0241)$ & $(0.164)$ \\
\hline No. of countries & 0.001 & 0.348 & 0.001 & 0.348 \\
\hline
\end{tabular}

NOTE: ${ }^{*},{ }^{* *}$, and ${ }^{* * *}$ denote 10 percent, 5 percent, and 1 percent statistical significance, respectively. Standard errors are in parentheses. GDP per capita denotes the natural logarithm of the GDP per capita variable. 
to countries with Taylor rule coefficients that are statistically significant at the 10 percent level and control for GDP per capita. This evidence shows that including the real exchange rate as part of the Taylor rule fundamentally affects the differential response to changes in expected inflation between open and closed economies estimated in the previous section. This evidence also suggests that differences in the responses to the real exchange rate may be a fundamental dimension along which these economies differ in the conduct of monetary policy.

6.2.2 Output Gap. The second panel of Table 5 reports the results of regressing the country-specific output gap Taylor rule coefficients on each country's aggregate exports-toGDP ratio. In contrast to the results presented in the previous section, I now find that open economies are estimated to assign a relatively higher weight on changes in the output gap; however, these estimates are statistically insignificant at the 10 percent level in all the specifications considered. Thus, I conclude that open economies do not systematically respond differently from closed economies to changes in the output gap.

6.2.3 Real Exchange Rate. The third panel of Table 5 reports the results of regressing the country-specific real exchange rate Taylor rule coefficients on each country's aggregate exports-to-GDP ratio. First, I find that open economies assign a lower (or more negative) weight on changes in the real exchange rate than closed economies do. And, moreover, I find that this relationship is statistically significant in all the specifications considered.

To quantify the economic importance of this relationship, I restrict attention to the results reported in column 4, where I control for GDP per capita and consider only Taylor rule coefficients that are statistically significant at the 10 percent level. On the one hand, consider that the average Taylor rule coefficient on the real exchange rate in this specification is equal to -0.11 . On the other hand, note that changing the aggregate exports-to-GDP ratio from its lowest to highest value across countries (from 0.093 to 0.567 ) is associated with a decrease in the value of the Taylor rule coefficient equal to -1.11 . This decrease suggests that open economies respond to a significantly larger extent to deviations of the real exchange rate from its trend than closed economies do. In particular, open economies are more likely to decrease the nominal interest rate when the real exchange rate is relatively appreciated (that is, when the real exchange rate is above trend).

6.2.4 Lagged Interest Rates. Finally, the bottom panel of Table (5) reports the results of regressing the country-specific sum of the interest rate lags of the Taylor rule on each country's aggregate exports-to-GDP ratio. As in the previous section, I find that there is no systematic relationship between the degree of a country's trade openness and the extent to which that country smooths interest rate adjustments over time in any of the specifications considered. Yet, as in the previous section, I find that richer economies smooth their nominal interest rate adjustments relatively more than poorer ones.

\section{CONCLUSION}

In this article, I study the extent to which open economies conduct monetary policy differently from closed economies. To do so, I apply the estimation approach of Clarida, Galí, and Gertler (1998 and 2000) to estimate country-specific Taylor rules for 26 economies and 
then examine whether open economies assign systematically different weights to changes in inflation and the output gap than their closed-economy counterparts do. I find that, indeed, open economies respond less strongly to changes in expected inflation than closed economies do; in contrast, I find that the response to changes in the output gap is independent of the degree of trade openness.

Moreover, I find that this difference between closed and open economies may be accounted for by the higher response of open economies to changes in the real exchange rate. Recomputing the analysis by extending the Taylor rule to allow nominal interest rates to respond to movements in the real exchange rate, I find that open economies no longer assign a systematically lower weight to inflation as closed economies do. Instead, I find that open economies respond more strongly to deviations of the real exchange rate from its trend.

It is important to remark that the analysis conducted in this article is subject to several caveats. An important one is that I restrict attention to differences in monetary policy as measured from the lens of the Taylor rule. To the extent that central banks may conduct monetary policy using instruments and targets that have no impact on the joint time-series dynamics of nominal interest rates, inflation, and the output gap, such policies would not be captured by my approach.

One question raised by these findings concerns the optimality of these differences in policymaking. To what extent should open economies indeed conduct monetary policy differently from closed economies along the dimensions documented in this article? And, if the observed differences in monetary policy are indeed suboptimal, then to what extent can open economies achieve better economic outcomes by conducting monetary policy in an optimal fashion? These are important questions left for further research. 


\section{Leibovici}

\section{NOTES}

1 Practically no country in the world can be accurately described to be a fully closed economy, since most countries trade with other countries to some extent. Nevertheless, throughout the rest of the paper, I sometimes loosely refer to economies that trade relatively less than others as "closed economies."

$\underline{2}$ A symmetric $J \times J$ matrix $W$ is positive definite if the scalar $\mathbf{x}^{\top} W \mathbf{x}$ is positive for every non-zero vector $\mathbf{x}$, where $\mathbf{x}^{\top}$ is the transpose of $\mathbf{x}$.

3 All variables used are based on the latest revised data; that is, the analysis is not conducted using real-time data and is subject to the limitations discussed in Orphanides (2001). Similarly, all filters (e.g., seasonal adjustment, detrending) applied to the data are based on the full sample and are not estimated on a real-time basis.

4 Thus, the variables that I use need not correspond exactly to the variables targeted by each of the country-specific central banks, even for countries in which monetary policy may be characterized as following a Taylor rule.

$\underline{5}$ For more information, see IMF (n.d.).

6 The GDP deflator is typically not the main variable used by central banks across the world, such as the Federal Reserve or European Central Bank, to measure inflation. Yet, in this article I restrict attention to measuring inflation based on the GDP deflator to maximize the cross-country comparability of the inflation measure.

7 Results are robust to other detrending procedures, such as computing the output gap as the cyclical deviation of real GDP from a Hodrick-Prescott trend with a smoothing parameter of 1,600.

8 Downloaded directly from the BIS website: https://www.bis.org/statistics/eer.

9 While there are data available extending beyond 2006 , I restrict attention to the pre-Great-Recession period to abstract from the measurement and modeling issues that would be introduced by having to deal with monetary policy at the zero lower bound.

10 For each country, I select the real exchange rate series used in the analysis as follows: (i) I use IMF data if there are at least 36 consecutive quarters available; (ii) otherwise, I use the BIS narrow real exchange rate data if there are at least 36 consecutive quarters available, (iii) otherwise, I use the OECD data if there are at least 36 consecutive quarters available; (iv) otherwise, I use the BIS broad real exchange rate data if there are at least 36 consecutive quarters available, and (v) otherwise, I exclude the country from the analysis.

11 These values correspond to the estimates from the second row of Table III in Clarida, Galí, and Gertler (2000).

12 Throughout the rest of the paper I refer to "not statistically different from zero" if a coefficient is not statistically significant at the 10 percent level.

$\underline{13}$ I interpret the estimated Taylor rule coefficients as empirical moments informative about the comovement among nominal interest rates with expected inflation, the output gap, and lagged nominal rates. Thus, for instance, I interpret negative and insignificant values of the Taylor rule coefficients as informative about the way in which a country conducts monetary policy, regardless of whether the country follows a Taylor rule or some other monetary policy regime.

14 Note that the Taylor rule coefficients estimated in the previous section are estimated with uncertainty. I abstract from this source of uncertainty when computing the standard errors reported in Table 3.

15 I measure the real exchange rate using the variables described in Section 4.2.

$\underline{16}$ I also include four lags of this variable as additional instruments.

17 Note that a negative coefficient on the real exchange rate implies that a depreciated real exchange rate (a low value of the real exchange rate relative to trend) is associated with a higher nominal interest rate; similarly, a positive coefficient implies that a depreciated real exchange rate is associated with a lower nominal interest rate. 


\section{REFERENCES}

Basilio, J.R. "Empirics of Monetary Policy Rules: The Taylor Rule in Different Countries." Ph.D. thesis, University of Illinois at Chicago, 2013.

Berument, H.; Konac, N. and Senay, O. "Openness and the Effectiveness of Monetary Policy: A Cross-Country Analysis." International Economic Journal, 2007, 21(4), pp. 577-91; https://doi.org/10.1080/10168730701699018.

Clarida, R.; Galí, J. and Gertler, M. "Monetary Policy Rules in Practice Some International Evidence." European Economic Review, 1998, 42(6), pp. 1033-67; https://doi.org/10.1016/S0014-2921(98)00016-6.

Clarida, R.; Galí J. and Gertler, M. "Monetary Policy Rules and Macroeconomic Stability: Evidence and Some Theory." Quarterly Journal of Economics, 2000, 115(1), pp. 147-80; https://doi.org/10.1162/003355300554692.

Clarida, R.; Galí J. and Gertler, M. "A Simple Framework for International Monetary Policy Analysis." Journal of Monetary Economics, 2002, 49(5), pp. 879-904; https://doi.org/10.1016/S0304-3932(02)00128-9.

Corsetti, G.; Dedola L. and Leduc, S. "Optimal Monetary Policy in Open Economies," in B.M. Friedman and M. Woodford, eds., Handbook of Monetary Economics. Volume 3. North-Holland, 2010, pp. 861-933; https://doi.org/10.1016/B978-0-444-53454-5.00004-9.

De Paoli, B. "Monetary Policy and Welfare in a Small Open Economy." Journal of International Economics, 2009, 77(1), pp. 11-22; https://doi.org/10.1016/j.jinteco.2008.09.007.

Faia, E. and Monacelli, T. "Optimal Monetary Policy in a Small Open Economy with Home Bias." Journal of Money, Credit, and Banking, 2008, 40(4), pp. 721-50; https://doi.org/10.1111/j.1538-4616.2008.00133.x.

Hayo, B. and Hofmann, B. "Comparing Monetary Policy Reaction Functions: ECB versus Bundesbank." Empirical Economics, 2006, 31(3), pp. 645-62; https://doi.org/10.1007/s00181-005-0040-7.

International Monetary Fund. "What Is the Central Bank Policy Rate?" N.d.; http://datahelp.imf.org/knowledgebase/articles/484375-what-is-the-central-bank-policy-rate, accessed December 10, 2018.

Kahn, G.A. "Estimated Rules for Monetary Policy." Federal Reserve Bank of Kansas City Economic Review, 2012, p. 5; https://www.kansascityfed.org/publicat/econrev/pdf/12q4Kahn.pdf.

Leibovici, F. and Santacreu, A.M. "International Trade Fluctuations and Monetary Policy." Working paper, 2015.

Lombardo, G. and Ravenna, F. "Openness and Optimal Monetary Policy." Journal of International Economics, 2014, 93(1), pp. 153-72; https://doi.org/10.1016/j.jinteco.2014.01.011.

Lubik, T.A. and Schorfheide, F. "Do Central Banks Respond to Exchange Rate Movements? A Structural Investigation." Journal of Monetary Economics, 2007, 54(4), pp. 1069-87; https://doi.org/10.1016/j.jmoneco.2006.01.009.

Orphanides, A. “Monetary Policy Rules Based on Real-Time Data." American Economic Review, 2001, 91(4), pp. 964-85; https://doi.org/10.1257/aer.91.4.964.

Taylor, J.B. "Discretion versus Policy Rules in Practice." Carnegie-Rochester Conference Series on Public Policy, 1993, 39, pp. 195-214; https://doi.org/10.1016/0167-2231(93)90009-L.

Torres, A. "Monetary Policy and Interest Rates: Evidence from Mexico." North American Journal of Economics and Finance, 2003, 14(3), pp. 357-79; https://doi.org/10.1016/j.najef.2003.08.001.

Yazgan, M. Ege and Yilmazkuday, H. "Monetary Policy Rules in Practice: Evidence from Turkey and Israel." Applied Financial Economics, 2007, 17(1), pp. 1-8; https://doi.org/10.1080/09603100600606206. 
